\title{
Entrepreneurship education in Romania. Realities and perspectives in secondary and high school
}

\section{Abstract}

\section{Gabriela Domilescu•}

The paper aims to analyze entrepreneurship education in Romania in terms of: concept, European educational policies in the field, actual status in the Romanian educational system and to advance proposals for improvement of entrepreneurial competences in Romanian education.

Thus, we will discuss the definition of entrepreneurship education, the most important European documents in the field and its benefits among students, as well as in society in general. We will present an analysis of the curricular documents in the Romanian secondary and high school education referring to entrepreneurhip education in terms of status, competencies, contents and values, discuss the necessity of entrepreneurial education in Romanian schools and identify ways of improving entrepreneurial competencies.

Keywords: entrepreneurship education, educational system, entrepreneurial competence

\section{Introduction}

Since 2008, Europe has been affected by the most severe economic crisis in the last 50 years (for the first time in Europe, the number of unemployed has exceeded 25 million people), which is why it has become essential to stimulate Europe's entrepreneurial potential, remove existing barriers and revolutionize entrepreneurial culture in Europe in order to facilitate the creation of new businesses and a more stimulating environment for prosperity and entrepreneurship growth.

In the 2009, the EU Council document (Conclusions of the Council and of the Representatives of the Governments of the Member States, on developing the role of education in a fully-functioning knowledge triangle) proposed to promote a creative, innovative and entrepreneurial perspective among pupils, trainees, students, teachers and researchers, which would support the progressive development of a wider entrepreneurial culture through education and training, as well as a more dynamic European labor market and a highly skilled workforce.

Although there has been significant progress in entrepreneurship education in Europe, its level remains low, with the Nordic countries having the best results (Nordic Innovation Report 2012) due to the integration of entrepreneurship education within the national education strategies. The report European Union: an overview of policies and practice Results of thematic survey

\footnotetext{
- Gabriela Domilescu - Ph.D., Teacher Training Department, West University of Timisoara, gabriela.domilescu@e-uvt.ro
} 
for the EU SME Envoys Network contains examples of good practice and challenges experienced by European states in the field of entrepreneurship education on different dimensions: the framework of entrepreneurship policies, partnerships, national curriculum and national qualifications framework, entrepreneurship education as an "eco-system" approach, monitoring and evaluation.

Statistics at European level indicate that Romania gives little importance to entrepreneurship education, so that less than $10 \%$ of those who have initiated and developed a business also have a theoretical basis in this respect compared to the European average of $30 \%$. The employment rate of the population aged $20-64$ in Romania $(63.9 \%$ in 2013$)$ is lower than the EU average $(68.5 \%$ in 2012), with the national target being 70\% by 2020 .

The European Commission's Entrepreneurship 2020 Action Plan published in 2013, states the importance of the emphasis placed on developing transversal and entrepreneurial competences in order to improve the employability of young people.

\section{Framework of analysis:}

In this context, the objectives of our work are: to advance a broad, modern concept of entrepreneurship education and competences, connected with nowadays social needs; to analyze entrepreneurship education (in Romanian secondary and high school) in terms of status, competencies, contents and values and to advance proposals to improve the acquisition of entrepreneurial competences in the Romanian pre-university education.

In order to achieve the above objectives, we analyzed the national and European educational policy documents in the field of entrepreneurship education and secondary and high school curriculum from the perspective of the entrepreneurial education in terms of: content, competencies, values.

\section{Entrepreneurship education - entrepreneurial competencies - entrepreneurial culture}

The concept/term of entrepreneurship education is relatively new, frequently used in recent years in Romania, but especially at European level, with variable specificity and complexity. Since 2006, the European Commission has stressed that education and training should support the development of entrepreneurship through entrepreneurship education, entrepreneurship referring to an individual's ability to turn ideas into action. Most European educational policy documents define "entrepreneurship" as " initiative", "a person's ability to turn ideas into action", "creativity, innovation and risk taking", "the ability to prepare and manage projects in order to achieve the objectives". Entrepreneurship as a competence applies to all spheres of life because it allows citizens to personally develop, actively contribute to social development, enter the labor market as an employee or on their own, and 
initiate or expand enterprises that may have a cultural, social or commercial ground.

The Recommendation 2006/962/EC on key competences for lifelong learning defines the sense of initiative and entrepreneurship as the ability to turn ideas into action through creativity, innovation and risk taking as well as the ability to plan and manage projects.

Entrepreneurial competence is one of the eight key competences established at European level and includes (ISE, European Key Competences) the following elements in terms of:

- Knowledge: identifying opportunities for personal, professional and/or business activities; broad understanding of economic activities, opportunities and challenges encountered by an employer or organization; awareness of the ethical position of enterprises and their beneficial force, honest exchanges and social activities.

- Abilities: proactive project management (planning, organizing, managing, delegating, analyzing, communicating, reviewing, evaluating,), effective representation and negotiation, the ability to work individually and in teams, the ability to assess and identify strengths and weaknesses, assessment and risk taking.

- Attitudes: initiative, proactivity, independence and innovation in personal, social and work life, motivation and determination to achieve the proposed goals, whether they are personal or established with others, including at work.

It is important to highlight and promote a broader acceptance of entrepreneurial competence, one that can apply to various contexts: education and training, work, personal life in general. According to the Danish Foundation for Entrepreneurship, "entrepreneurship is when you act upon opportunities and ideas and transform them into value for others. The value that is created can be financial, cultural, or social" and, as a consequence entrepreneurship education refers to "content, methods and activities supporting the creation of knowledge, competencies and experiences that make it possible for students to initiate and participate in entrepreneurial value creating processes" (Moberg et al., 2012, p.14 in Lackéus, M., 2015).

Entrepreneurship can be an important element from the point of view of autonomy, personal development and youth welfare, and it is considered one of the available and promising solutions to combat youth unemployment. This is the reason why Europe should invest in entrepreneurship education and training, in creating an environment in which entrepreneurs can best realize their potential and develop, in communicating with specific groups, as well as in the visibility of entrepreneurs as models.

Nowadays we talk about "social entrepreneurship", "digital entrepreneurship" or even "green entrepreneurship".

Social entrepreneurship aims to provide innovative solutions to unsolved social problems. Therefore, it often goes hand in hand with social innovation processes, aimed at improving people's lives by promoting social change (OECD, 2010). Social entrepreneurship primarily aims at contributing to the common 
social good, having the potential to attract young people and offer them the opportunity to bring innovative solutions to the current economic, social and environmental challenges. This concept of social entrepreneurship that is close to people and local communities can help counterbalance the major societal challenges that come from both the public and private sectors as well as from civil society and social economy organizations. The main objectives of social entrepreneurship are: to generate social value, to reduce poverty for as long as possible by creating new jobs for disadvantaged people, to increase the number of employed individuals and to sustainable economic development.

Digital entrepreneurship involves the use of new digital technologies (particularly social media, big data, mobile and cloud solutions), having as main purposes: to improve business operations, invent new business models, improve business intelligence or to engage with customers and stakeholders (Bacigalupo, M., Kampylis, P., Punie, Y., Van den Brande, G., 2016, p.20).

Green entrepreneurship has a positive effect on environment and can be seen as a move to a more sustainable future (Schaper, 2012).

A very effective tool for building entrepreneurship competences is the EntreComp model, designed by the European Commission, over a period of 18 months. The EntreComp framework was developed through a mixed-methods approach and proposes a shared definition of entrepreneurship as a competence in order to establish a bridge between the worlds of education and work.

The EntreComp conceptual model "is made up of two main dimensions: the 3 competence areas that directly mirror the definition of entrepreneurship as the ability to turn ideas into action that generate value for someone other than oneself; and the 15 competences that, together, make up the building blocks of the entrepreneurship as a competence for all citizens" (Bacigalupo, M., Kampylis, P., Punie, Y., Van den Brande, G., 2016, p.10). The 3 interrelated and interconnected competence areas are: "Ideas and opportunities", "Resources" and "Into action". The framework develops the 15 competences along an 8-level progression model and proposes a comprehensive list of 442 learning outcomes. The framework can be used as a basis for the development of curricula and learning activities fostering entrepreneurship as a competence and for the guidance of the efforts of teachers, policy makers, employers to develop and assess the competence of students, students, employees.

Currently, there is a Memorandum of Understanding for a European Curriculum for entrepreneurship Education under DOIT (Entrepreneurial skills for young social Innovators in an open digital world), a project under the program HORIZON 2020 Innovation Action, which aimed to propose a set of general approaches and actions that can contribute to the promotion of national and regional educational policies and practices through the DOIT concept.

Therefore, a radical change of European culture is needed towards a new concept of entrepreneurship in order to: publicly celebrate success in various fields, bring entrepreneurs to the forefront of European prosperity, present the advantages of an entrepreneurial career. Entrepreneurial culture means both the ability of the individual to accept and support the new, to assume the 
responsibility of their own decisions and actions and the ability to identify opportunities for professional development and business.

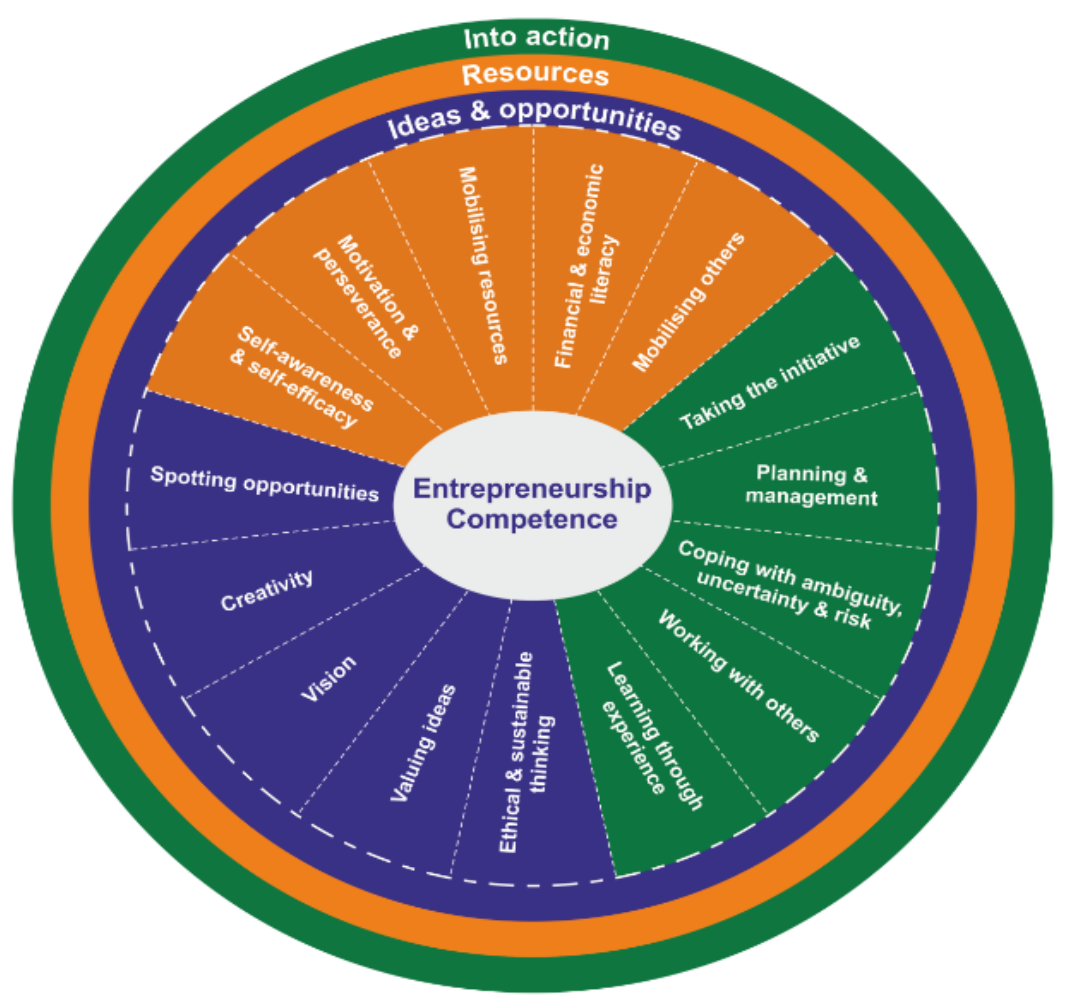

Figure 1: Areas and competences of EntreComp framework

Until recently, in Europe, we could not discuss about the existence of an entrepreneurial culture in education, in most European countries, entrepreneurship education being part of the curriculae only in secondary education. Recently, in the European countries, key and transversal (that can be transferred from one specific professional field to another) competences, such as entrepreneurship, are widely integrated into primary and secondary school curricula, because the European states are aware of their importance, considering that initial education and training must provide all young people with the means to develop their skills (up to a level that will prepare them for adult and professional life) in order to form a basis for future learning (http://www.proiectdantes.eu/ informative / index.php / competenteentrepreneurial-and-training).

\section{Entrepreneurial skills in Romanian secondary and high school education}

In order to establish an accurate picture of entrepreneurship education in Romania, in terms of concept and status, we analyzed relevant national 
curricular documents: all elementary, secondary and high school study plans and syllabuses from secondary and high school subjects.

After the analysis of all elementary, secondary and high school study plans we found that entrepreneurship education does not appear as a separate subject in the curriculum, either at primary or at secondary level, although it is the subject that might best contribute to the achievement of one of the eight key European competences: sense of initiative and entrepreneurship. Romanians pupils study entrepreneurship education only in the 10th grade, one hour per week.

After analyzing the study plans, we selected 20 syllabuses, having the potential of developing entrepreneurial competences, but, after a preliminary analysis, we decided to study 17 sylabusses in terms of: general and specific competences, contents and values and attitudes, as follows:

1. Entrepreneurship education, $10^{\text {th }}$ grade, core curriculum

2. Civic education, for high school, elective curriculum

3. Civic culture, 5 th grade, core curriculum

4. Counselling and personal development, secondary level, core curriculum

5. Applied economics, $12^{\text {th }}$ grade, technological profile, direct/progressive professional qualification route

6. Civic culture, $6^{\text {th }}$ grade, elective curriculum

7. Economics, $11^{\text {th }}$ grade, core curriculum

8. Economic education, 5th grade, elective curriculum

9. Economic education, 6th grade, elective curriculum

10. Financial education, high school, elective curriculum

11. Financial education, secondary school, elective curriculum

12. Financial education, primary school, elective curriculum

13. Education for development, high school, elective curriculum

14. Project management, $11^{\text {th }}$ grade, pedagogic profile, high school, elective curriculum

15. Animator instructor, trainer for extra-activities, high school, elective curriculum

16. Education for democracy, high school, elective curriculum

17. Social education, 8 th grade, core curriculum

\section{Results and discussions:}

From the analysis of the above mentioned curricular documents, we believe that the following elements are worthy of discussions:

- Nine of the syllabuses have the same set of general competencies, belonging to social sciences: the use of specific social concepts in the organization of knowledge and explanation of facts, events, and real life processes; the application of specific social sciences information in solving problematic situations, as well as in analyzing the personal possibilities for development; cooperating with others in solving theoretical and practical problems within different groups; expressing 
an active and responsible social behavior appropriate to a changing world; participation in decision-making and community problem solving;

- Difficulties in properly formulating the competences of the abovementioned subjects (a problematic integration of knowledge, aptitudes and attitudes) can be frecquently found;

- even in the case of subjects that approach specific contents of entrepreneurship education, the formulation/wording/statement of entrepreneurial competences is deficient and they are formulated in a technical manner;

- only four of the syllabuses are part of the core curriculum (Social Education, Counseling and Personal Development in secondary school and Entrepreneurship Education and Economics at High School), the others being part of elective subjects (school decision);

- the contents of these programs are diverse, from the development of pro-social behaviors, in the case of several subjects, to specific business and entrepreneurial information, with large applicability and utility in practice (Entrepreneurs and Businesses; Consumers and their rational behavior; Market-meeting of economic agents; Cost and profit; Production costs; The wage. Income and education; Money. Inflation; Unemployment; Needs and projects of individuals and families; What is a good entrepreneur; Famous business people; Business ideas, Profit;

- the main values promoted by the subjects approaching and facilitating entrepreneurship education are: economic rationality (Economics, Entrepreneurship Education, Applied Economics, Financial Education); entrepreneurial spirit (Economics, Entrepreneurship Education); economic efficiency (Entrepreneurship Education, Economics, Applied Economics); positive relationships with others (Civic Culture, Financial Education, Education for Development, Education for Democracy);

- entrepreneurship education, studied in high school, in the 10th grade at all profiles and specializations, one hour each week, has, according to the official curricular documents, the following competences: the use of specific entrepreneurship education concepts for organizing the knowledge and explaining facts, events, real life processes; application of entrepreneurial specific knowledge in market economy situations as well as in analyzing the possibilities of personal development; cooperation within different groups to solve theoretical and practical problems specific to the business environment; assessing the appropriate behavior of a changing economic and social environment; formulating opinions in order to solve community problems, on initiating and conducting business.

- Considering the above presented aspects, both in terms of educational policies and concret curricular documents, in our opinion, there are several ways to improve entrepreneurial competences in Romanian pre- 
university education, which could be applied easily and without too many costs:

- updating, as soon as possible, the sylabusses approaching entrpreneurship education according to new scientific and pedagogic approaches in the field, both in terms of content, competences and methodes;

- expanding the vision of entrepreneurship education and entrepreneurial competences by the dissemination of the EntreComp model, within an official, well organized approach;

- increasing the awareness among teachers and decision-makers of the importance of understanding what really entrepreneurship education means and how entrepreneurial competences can be easily and comprehensively achieved;

- integrating (partially or fully) the entrepreneurial competences from the EntreComp model into the set of competencies of other subjects that can successfully contribute to their achievement.

Analyzing the competences of the EntreComp model, we consider that all disciplines that are part of the actual Romanian curriculum could successfully contribute to their achievement. Furthermore, all these competencies have a positive impact on the entire development (academic, professional, social and personal) of young people, reasons why it is necessary to popularize this model that can dramatically change the perception of entrepreneurship education in Romanian schools and among teachers and principals.

Recent studies of the European Commission demonstrate the multiple impact of entrepreneurship education, and policy makers and educational leaders increasingly recognize how entrepreneurial attitudes and abilities can bring individual benefits (evolving professional ambitions, greater employability, improving entrepreneurial attitudes and abilities, the development of entrepreneurial intentions, the emergence of intentions to start a business in secondary education), institutional (developing a stronger entrepreneurial culture, greater involvement of teachers, intensifying engagement of stakeholders), economic growth generating a high return on investment) and social (prevention of social exclusion).

\section{Acknowledgement:}

This research was realized within the project START UP BANAT, POCU 103886. We thank our colleague Ph. D. Marian Ilie form the West University of Timisoara who provided insight and expertise that assisted the research, although he may not agree with all of the interpretations/conclusions of this paper.

\section{References:}

Bacigalupo, M., Kampylis, P., Punie, Y., Van den Brande, G. (2016). EntreComp: The Entrepreneurship Competence Framework. Luxembourg: Publication Office of the European Union; EUR 27939 EN; doi:10.2791/593884 
CONSILIUL UNIUNII EUROPENE (2015). Concluzii ale Consiliului privind antreprenoriatul în educație și formare (2015/C 17/02), în Jurnalul Oficial al Uniunii Europene Jurnalul Oficial al Uniunii Europene, https://eur-lex.europa.eu

CONSILIUL UNIUNII EUROPENE (2014). Concluziile Consiliului din 20 mai 2014 privind promovarea antreprenoriatului în rândul generației tinere în vederea sprijinirii incluziunii sociale a tinerilor (2014/C 183/04), în Jurnalul Oficial al Uniunii Europene, https://eur-lex.europa.eu

CONSILIUL UNIUNII EUROPENE (2009). Recomandările Consiliului și ale reprezentanților guvernelor statelor membre, reuniți în cadrul Consiliului, din 26 noiembrie 2009 privind dezvoltarea rolului educației în cadrul unui triunghi al cunoașterii complet funcțional (2009/C 302/03), în Jurnalul Oficial al Uniunii Europene https://eur-lex.europa.eu

DOIT. (2019).(Preliminary) Memorandum of understanding for a European curriculum for entrepreneurship education building upon the doit Concept, http://DOIT-Europe.net

EUROPEAN COMMISSION (2016). Entrepreneurship Education at School in Europe, Eurydice Report. Luxembourg: Publications Office of the European Union, https:// eacea.ec.europa.eu/national-policies/eurydice/content/entrepreneurship-educationschool-europe en

EUROPEAN COMMISSION (2011), Teacher Education for Entrepreneurship: Towards a Development Agenda. A report and evaluation of the pilot action on training teachers for entrepreneurship education initiated by the European Commission. ECORYS: United Kingdom, http://www.cop-ie.eu/node/381

EUROPEAN COMMISSION (2011), Entrepreneurship Education: Enabling Teachers as a Critical Success Factor: A report on Teacher Education and Training to prepare teachers for the challenge of entrepreneurship education, http://ec.europa.eu/ enterprise/policies/sme/ promotingentrepreneurship/ files/education/ teacher_ education_for_entrepreneurship_final_report_en.pdf

EUROPEAN COMMISSION (2011). Mapping of teachers' preparation for entrepreneurship education. Education and Culture Directorate-General. GHK: Brussels, http://ec.europa.eu/ education/more-information/doc/2011/mapping_en.pdf

EUROPEAN COMMISSION (2006). Recommendation of the European Parliament on Key competences for lifelong learning, Retrieved from http://eurlex.europa.eu EUROPEAN COMMISSION (2006). Implementing the Community Lisbon Programme: Fostering entrepreneurial mindsets through education and learning. Commission for the European Communities: Brussels, Retrieved from http://eurlex.europa.eu

LACKÉUS, M. (2015). Entrepreneurship in education - what, why, when, how. Entrepreneurship. Background Paper. Paris: OECD, 2015, http://www.oecd.org/ cfe/leed/BGP Entrepreneurshipin-Education.pdf

OECD. (2010). Social Entrepreneurship and Social Innovation SMEs, Entrepreneurship and Innovation. Paris: OECD Publishing.

Schaper, M. (2012). Understanding the green Entrepreneur. In M. Schaper (Ed.), Making Ecoentrepreneurs: Developing Sustainable Entrepreneurship. Farnham, Surrey: Gower Publishing.

SEECEL. (2015). European Union: an overview of policies and practice Results of thematic survey for the EU SME Envoys Network, http://ec.europa.eu/transparency/regexpert

http://www.proiectdantes.eu/informative/index.php/competente-antreprenoriale-siformare 